\title{
ROR $\beta$ suppresses the stemness of gastric cancer cells by downregulating the activity of the Wnt signaling pathway
}

\author{
ZHENZHEN WEN $^{1}$, MING CHEN $^{1}$, WENHAO GUO $^{2}, \mathrm{KE} \mathrm{GUO}^{1}$, PING DU $^{1}$, \\ YANFEI FANG ${ }^{1}$, MIN GAO $^{1}$ and QIANG WANG ${ }^{3}$
}

\begin{abstract}
Departments of ${ }^{1}$ Gastroenterology and ${ }^{2}$ Pathology, Sir Run Run Shaw Hospital, School of Medicine, Zhejiang University, Hangzhou, Zhejiang 310016; ${ }^{3}$ Department of Hepatopancreatobiliary Surgery and Minimally Invasive Surgery, Zhejiang Provincial People's Hospital, Hangzhou Medical College, Hangzhou, Zhejiang 310014, P.R. China
\end{abstract}

Received December 8, 2020; Accepted April 27, 2021

DOI: $10.3892 /$ or.2021.8131

\begin{abstract}
Gastric cancer (GC) is the third leading cause of cancer-related mortality and the fifth most common type of cancer worldwide. GC stem cells (GCSCs) have been reported to be responsible for the malignant behavior of GC. However, the key molecular mechanism controlling GCSC function remains unclear. The present study aimed to investigate the function of retinoic acid-related orphan receptor $\beta(R O R \beta)$ in GC. The expression levels of ROR $\beta$ in GC cells and clinical GC tissues were analyzed using western blotting, reverse transcription-quantitative PCR (RT-qPCR) and immunohistochemistry. The association between ROR $\beta$ expression levels and GCSC markers was analyzed using Gene Set Enrichment Analysis, and GeneChip was performed to identify differentially expressed genes between control and ROR $\beta$-overexpressing GC cells. CCK-8 and flow cytometric assays were used to evaluate the effect of $\operatorname{ROR} \beta$ on cell viability and apoptosis, respectively. The effect of ROR $\beta$ on the self-renewal capacity of GCSCs was measured using a sphere formation assay, the expression levels of induced pluripotent stem (iPS) factors and epithelial-mesenchymal transition (EMT)-related factors were measured by RT-qPCR and western blotting, and the tumorigenic capacity was measured by an in vivo mouse model. Finally, the impact of ROR $\beta$ on the Wnt signaling pathway was determined using western blotting and a TOP/FOP flash assay. The results revealed that the expression levels of ROR $\beta$ were downregulated in GC tissues compared with para-carcinoma tissues, and were inversely associated with the expression levels of GCSC markers. The overexpression of ROR $\beta$ upregulated
\end{abstract}

Correspondence to: Dr Qiang Wang, Department of Hepatopancreatobiliary Surgery and Minimally Invasive Surgery, Zhejiang Provincial People's Hospital, Hangzhou Medical College, 158 Shang Tang Road, Hangzhou, Zhejiang 310014, P.R. China E-mail: wangqiang@hmc.edu.cn

Key words: gastric cancer, gastric cancer stem cells, self-renewal, Wnt signaling pathway, retinoic acid-related orphan receptor $\beta$, epithelial-mesenchymal transition the expression levels of the pro-apoptotic gene, Bcl-2 like protein 11, which subsequently inhibited the viability and promoted the apoptosis of GC cells. In addition, ROR $\beta$ decreased the sphere forming ability, and downregulated the expression levels of iPS cell- and EMT-related factors. In vivo, ROR $\beta$ suppressed the tumorigenic capacity and stemness of GC cells. Mechanistically, ROR $\beta$ was revealed to decrease the activity of the Wnt/ $\beta$-catenin signaling pathway in GCSCs. In conclusion, the findings of the present study identified ROR $\beta$ as a novel suppressor of GCSCs and highlighted the prospect of ROR $\beta$ as a novel candidate target for stem cell-based GC therapy.

\section{Introduction}

Gastric cancer (GC) is the fifth most common type of cancer worldwide and the third leading cause of cancer-related mortality, with approximately 951,600 cases and 723,100 GC-related deaths in 2012 (1). Common therapeutic strategies for GC include surgical resection, chemotherapy, radiotherapy and anti-angiogenic therapy (2). However, the efficacy of current treatment regimens for GC are hindered by multiple factors such as chemotherapy and radiotherapy resistance, and tumor relapse (3). At present, cancer stem cells (CSCs) are regarded as a crucial population contributing to the irresponsiveness to GC treatment and the poor prognosis (4). CSCs can initiate tumor formation, and promote self-renewal, therapy resistance, metastasis and tumor recurrence $(5,6)$. As a result, it is of great importance to determine the key molecules controlling the malignant properties of gastric CSCs (GCSCs).

GCSCs were first identified in 2007 by Yang et al (7). CD44, CD24/CD44 and aldehyde dehydrogenase (ALDH)1 have been identified as GCSCs markers $(8,9)$. Numerous previous studies have revealed the therapeutic value of targeting CSC markers for GC intervention; for example, Gong et al (10) reported that leucine rich repeat containing G protein-coupled receptor 5 (LGR5) antibody conjugates induced cytotoxicity in GC cells overexpressing LGR5. In addition, all-trans retinoic acid treatment inhibited GC progression in mouse xenograft models by downregulating the expression levels of CD44 and ALDH1 (11). Recently, an increasing number of therapeutics targeting 
stemness-associated functions have been designed to specifically eradicate GCSCs, including those that inhibit stemness-associated genes, block self-renewal signaling pathways and microenvironment-based anti-GCSC therapies (12). One of the most characterized pathways contributing to the function of CSCs is the Wnt signaling pathway, and the aberrant activation of the Wnt signaling pathway has been revealed to promote stem cell characteristics of CSCs and initiate the epithelial-mesenchymal transition (EMT) process (13). Due to the pivotal role of CSCs in tumor progression and metastasis, an improved understanding of the regulatory elements that control the malignant behaviors of GCSCs may lead to the development of effective therapies for patients with GC.

Retinoic acid-related orphan receptor $\beta(\operatorname{ROR} \beta)$ is a member of the orphan nuclear receptor family (14). ROR $\beta$ was originally considered to be expressed solely in the central nervous system (CNS), mainly in the regions modulating the circadian rhythm (15). However, ROR $\beta$ has since been demonstrated to be expressed in other regions of the body, including bone tissue, pancreatic cancer tissue and colorectal cancer tissue $(16,17)$. Risinger et al reported that the expression levels of ROR $\beta$ were upregulated in women with endometrial cancer compared with healthy women (18). However, despite the reported expressional changes of $\operatorname{ROR} \beta$, the pathological significance of $\operatorname{ROR} \beta$ remains largely unknown. Therefore, the present study aimed to investigate the expression levels and function of ROR $\beta$ in GC, and identified ROR $\beta$ as a novel suppressor of GCSCs. These findings may help to propose a valuable target for the stem cell-based therapy of GC in the future.

\section{Materials and methods}

Patient studies. A total of 32 patients with GC at the General Surgery Department of Sir Run Run Shaw Hospital (Hangzhou, China) were selected from January 2019 to December 2019. There were 18 males and 14 females with an age range of 34-76 years (average age 61.5 years old). The fresh operative GC tissues and corresponding para-cancerous tissues were collected. The pathological stage was determined according to the American Joint Committee on Cancer (AJCC) and the International Union against Cancer (UICC) seventh edition TNM staging system (19). The inclusion criteria were as follows: i) radical gastrectomy or palliative surgery for GC and pathological diagnosis was GC; ii) preoperative radiotherapy, and chemotherapy were not performed; iii) complete clinicopathological data were available. The exclusion criteria were as follows: i) gastric cancer recurrence or residual gastric cancer; ii) combined with organ dysfunction or other tumors. All patients provided written informed consent prior to participation and the present study was approved by the Institutional Review Board from Sir Run Run Shaw Hospital (approval no. 20210429-30).

Cell culture. GC cell lines, AGS and MKN45, were purchased from The Cell Bank of Type Culture Collection of the Chinese Academy of Sciences. AGS cells were cultured in DMEM (Gibco; Thermo Fisher Scientific, Inc.) supplemented with 10\% FBS (Thermo Fisher Scientific, Inc.), while MKN45 cells were cultured in RPMI-1640 medium (Gibco; Thermo Fisher
Scientific, Inc.) supplemented with $10 \%$ FBS. All GC cells were incubated at $37^{\circ} \mathrm{C}$ and $5 \% \mathrm{CO}_{2}$. GCSCs were cultured from GC cells at a density of $1 \times 10^{5}$ cells $/ \mathrm{ml}$ in serum-free medium. EGF (20 g/l; Invitrogen; Thermo Fisher Scientific, Inc.), bFGF (20 g/l; Invitrogen; Thermo Fisher Scientific, Inc.), B27 (2\%; Invitrogen; Thermo Fisher Scientific, Inc.), BSA (0.4\%; Roche Diagnostics), insulin (4 mg/l; Invitrogen; Thermo Fisher Scientific, Inc.) and gentamicin (200 IU/ml; Sangon Biotech, Co., Ltd.) were added to DMEM/F-12 (Gibco; Thermo Fisher Scientific, Inc.) in 4-well low adhesion culture plates in an incubator at $37^{\circ} \mathrm{C}$ with $5 \% \mathrm{CO}_{2}$ for $7-10$ days.

Screening and identification of stable ROR $\beta$-overexpression $G C$ cells. The ROR $\beta$ gene coding sequence from ROR $\beta /$ pReceiver plasmid (GeneCopoeia, Inc.) was inserted into pEGFP-C1 vector at the BamHI site and identified by DNA sequencing (Sangon Biotech Co., Ltd.). GC cells were seeded into 6 -well plates at a density of $1 \times 10^{6}$ cells/well at $37^{\circ} \mathrm{C}$ with $5 \% \mathrm{CO}_{2}$ for $24 \mathrm{~h}$. ROR $\beta / \mathrm{pEGFP}-\mathrm{C} 1(4 \mu \mathrm{g} / \mu \mathrm{l})$ and pEGFP-C1 vector $(4 \mu \mathrm{g} / \mu \mathrm{l})$ were transfected into $\mathrm{GC}$ cells using Lipofectamine ${ }^{\circledR} 3000$ reagent (Invitrogen; Thermo Fisher Scientific, Inc.). After 2 days, the cells were cultured in the presence of $500 \mu \mathrm{g} / \mathrm{ml} \mathrm{G} 418$ (Invitrogen; Thermo Fisher Scientific, Inc.) for 2 weeks to obtain stably transfected GC cells. ROR $\beta$-overexpression GC cells were further verified by western blotting.

Screening stable ROR $\beta$-knockdown GC cells. GC cells were transfected with $4 \mu \mathrm{g} / \mu \mathrm{l}$ ROR $\beta$-short hairpin (shRNA) and $4 \mu \mathrm{g} / \mu \mathrm{l}$ control shRNA (both from Santa Cruz Biotechnology, Inc.) using Lipofectamine ${ }^{\circledR} 3000$ reagent (Invitrogen; Thermo Fisher Scientific, Inc.) for 2 days and then the cells were screened with puromycin $(5 \mu \mathrm{g} / \mathrm{ml})$ for 14 days to obtain the stable ROR $\beta$-knockdown cells further verified by western blotting.

Nuclear/cytosolic fractionation. Ice-precooled CER I (200 $\mu \mathrm{l})$ was added to GC cells and the cells were incubated on ice for $10 \mathrm{~min}$ after vortex oscillation for $15 \mathrm{sec}$ using nuclear and cytoplasmic extraction reagents (NE-PER) (Pierce; Thermo Fisher Scientific, Inc.). Ice-precooled CER II (11 $\mu \mathrm{l})$ was added and incubated, then swirled and shaken for $5 \mathrm{sec}$, and incubated on ice for $1 \mathrm{~min}$. The supernatant (cytoplasm) was transferred to a clean ice-precooled centrifuge tube for preservation on ice. The sediment was suspended with ice-precooled NER $100 \mu 1$, incubated on ice for $10 \mathrm{~min}$, and vortex oscillated 4 times for $15 \mathrm{sec}$. After centrifugation at $16,000 \mathrm{x}$ g for $10 \mathrm{~min}$ at $4{ }^{\circ} \mathrm{C}$, the supernatant was transferred to a clean ice-precooled centrifuge tube (cell nucleus), and then western blotting was performed.

Sphere formation assay. ROR $\beta$-overexpression and ROR $\beta$-knockdown GC cells and control cells were digested and cultured in 24-well plates at a density of 200 cells/well in serum-free medium incubated at $37^{\circ} \mathrm{C}$ with $5 \% \mathrm{CO}_{2}$ for 7 days. The medium was replaced every 3-4 days. Following the incubation, the spheres were counted manually using a light microscope with a magnification of $\mathrm{x} 20$.

$C C K-8$ assay. ROR $\beta$-overexpression and ROR $\beta$-knockdown cells and control cells were seeded into 96-well plates at a 
density of $1 \times 10^{4}$ at $37^{\circ} \mathrm{C}$ with $5 \% \mathrm{CO}_{2}$ for $24 \mathrm{~h}$. Following incubation, $10 \mu \mathrm{l}$ CCK-8 reagent (Abcam) was added/well and incubated for $4 \mathrm{~h}$. Subsequently, the absorbance value was measured with a microplate reader at a wavelength of $460 \mathrm{~nm}$.

Flow cytometric analysis of apoptosis. ROR $\beta$-overexpression GC cells and control cells were trypsinized, and $1 \times 10^{6} / \mathrm{ml}$ cells were collected by centrifugation $\left(300 \mathrm{x} \mathrm{g}, 5 \mathrm{~min}\right.$ at $\left.4^{\circ} \mathrm{C}\right)$. Cells were washed with PBS twice and incubated in $500 \mu \mathrm{l}$ binding buffer, $5 \mu \mathrm{l}$ Annexin V-EGFP and $10 \mu \mathrm{l}$ propidium iodide at room temperature in the dark for 15 min using Annexin V-FITC/PI Apoptosis Detection Kit (Beyotime Institute of Biotechnology) according to the manufacturer's instructions. Apoptotic cells were visualized and quantified using FACSAria (BD Biosciences) with FlowJo software (version 7.6.1; Tree Star, Inc.).

Nude mouse xenograft model. All animal experiments were approved by the Institutional Animal Care and Use Committee of Zhejiang University (Hangzhou, China) and complied with the Animal Welfare Act (20). BALB/c nude mice (30 females; 4 weeks old; body mass 17-20 g) were purchased from Shanghai Laboratory Animal Center. The mice were bred at the Laboratory Animal Research Center at Sir Run Run Shaw Hospital in a barrier environment, specific pathogen-free (SPF) grade, with humidity approximately 30 to $50 \%$ at $22^{\circ} \mathrm{C}$. In addition, water and food was provided ad libitum. A total of $0.2 \mathrm{ml}$ ROR $\beta$-overexpression GC cells and control cells (at the density of $1 \times 10^{5}, 5 \times 10^{5}$ and $1 \times 10^{6}$ ) were subcutaneously inoculated into the backs of nude mice. There were five mice in each group. Tumor growth was observed weekly, and rats were sacrificed by cervical spinal cord transection after 4 weeks, and the tumor body was measured and analyzed. The tumor volumes were assessed according to the diameters of the tumors.

Immunohistochemistry (IHC). All GC tissue specimens were fixed with $10 \%$ neutral formaldehyde solution for 4-6 $\mathrm{h}$ at room temperature, and were routinely dehydrated, waxed and wrapped. Then, the tissues were cut into $3-\mu \mathrm{m}$ sections. The tissue sections were baked at $60^{\circ} \mathrm{C}$ overnight. Then, the tissue sections were subsequently deparaffinized by the following method: After baking, the tissue slices were immersed in xylene at room temperature twice for $10 \mathrm{~min}$ each. Then they were immersed in $100 \%$ ethanol for $5 \mathrm{~min}$. Next, the tissue sections were rehydrated in 100, 85 and $70 \%$ ethanol at room temperature for $2 \mathrm{~min}$ respectively. Finally, the slices were incubated at $90^{\circ} \mathrm{C}$ in deionized water for $30 \mathrm{~min}$. Subsequently, the slices were boiled in citric acid buffer solution and maintained at a low heat for $30 \mathrm{~min}$. The sections were then sealed with 5\% BSA (Sangon Biotech Co., Ltd.) in a wet box at $37^{\circ} \mathrm{C}$ for $30 \mathrm{~min}$ and air-dried. The sections were then incubated in a wet box at $4^{\circ} \mathrm{C}$ overnight with an anti-ROR $\beta$ antibody (cat. no. NBP1-82532; 1:300; Novus Biologicals, LLC). Following the primary antibody incubation, the sections were rinsed thrice with PBS for 5 min and incubated with $50 \mu \mathrm{l}$ of an HRP-conjugated secondary goat anti-rabbit antibody (product code ab6721; 1:1,000; Epitomics; Abcam) at room temperature for $20 \mathrm{~min}$. Then the sections were rinsed thrice with PBS for $3 \mathrm{~min}$. The slides were observed under a light microscope with a magnification of $\mathrm{x} 100$.
Wound healing assay. MKN45 and AGS cells were plated into 96-well plates and incubated overnight. Approximately $1 \times 10^{4}$ cells in each well were serum-starved overnight, and then the head of the pipette tip was used to produce a scratch in the cell monolayer. The cells were then washed with PBS 3 times to remove the unattached cells and subsequently incubated in fresh culture medium without FBS for indicated time-points at $37^{\circ} \mathrm{C}$. Images of the wound were captured at 0,12 and $24 \mathrm{~h}$ using a light microscope (magnification, $\mathrm{x} 20$ ). The percentage of migration area was calculated using ImageJ software $(1.52 \mathrm{v}$; National Institutes of Health).

F-actin polymerization experiment. AGC cells grown on cover-slips inside a petri dish were transfected with ROR $\beta /$ pReceiver plasmid and control and were incubated at $37^{\circ} \mathrm{C}$ for 2 days using Lipofectamine ${ }^{\circledR} 3000$ reagent (Invitrogen; Thermo Fisher Scientific, Inc.). The cells were washed once with PBS. Then, the cells were incubated with 3-4\% formaldehyde in PBS at room temperature for $30 \mathrm{~min}$. The staining solution was aspirated carefully and the fixed cells were washed 2-3 times in PBS. Conjugate working solution 1X Phalloidin-iFluor ${ }^{\mathrm{TM}} 488$ (AAT Bioquest, Inc.) was added to the fixed cells. Subsequently, the cells were incubated at room temperature for $60 \mathrm{~min}$. DAPI staining solution (BIOSS) was then added and the cells were incubated at room temperature for $5 \mathrm{~min}$. The cells were rinsed gently 2-3 times with PBS to remove excess phalloidin conjugate. Mounting medium was added and sealed. The cells were observed at a magnification of $\mathrm{x} 400$ under a fluorescence microscope (Olympus Corporation) with an FITC filter set.

Reverse transcription-quantitative PCR (RT-qPCR). Total RNA from GC cells was extracted using RNeasy Mini Kit (cat. no. 74104; Qiagen $\mathrm{GmbH}$ ) and then reverse transcribed into cDNA using PrimeScript RT reagent kit (cat. no. RR037A; Takara Bio, Inc.) according to the manufacturer's protocol. RT-qPCR was performed using Premix Ex Taq (cat. no. RR420A; Takara Bio, Inc.). The thermocycling conditions were as follows: Initial denaturation at $95^{\circ} \mathrm{C}$ for $5 \mathrm{~min}$; annealing and elongation at $95^{\circ} \mathrm{C}$ for $30 \mathrm{sec}, 95^{\circ} \mathrm{C}$ for $5 \mathrm{sec}, 60^{\circ} \mathrm{C}$ for $34 \mathrm{sec}$ for 40 cycles; and final extension at $60^{\circ} \mathrm{C}$ for $10 \mathrm{~min}$. The sequences of the primer pairs used were: Oct4 forward, 5'-GTGGAGGAAGCTGACAACAA-3', reverse, 5'-AACAAATTCTCCAGGTTGCC-3' and probe, 5'-Fam-TCTCTTTCGGGCCTGCACGA-3'Tamra; Sox 2 forward, 5'-AATGCCTTCATGGTGTGG-3', reverse, 5'-CTT CTCCGTCTCCGACAAA-3', and probe, 5'Fam-AGTTTC CACTCGGCGCCCAG-3'Tamra; KLF4 forward, 5'-GGCACT ACCGTAAACACACG-3', reverse, 5'-CTGGCAGTGTGG GTCATATC-3', and probe, 5'Fam-CAGGTCGGACCACCT CGCCT-3'Tamra; CD44 forward, 5'-TGGCAACAGATGGCA TGAGG-3', reverse, 5'-CCTTGCATTGGATGGCTGGT-3' and probe, 5'Fam-AACAGGGACAGCTGCAGCCTCAGC T-3'Tamra; ALDH1 forward, 5'-GCTGGCGACAATGGA GTCAA-3', reverse, 5'-TGTACGGCCCTGGATCTTGT-3' and probe, 5'Fam-ACATTGCGCTACTGTGCAGGTTGG GCT-3' Tamra; Slug forward, 5'-TCACTGTGTGGACTA CCGCT-3', reverse, 5'-TCGCCCCAAAGATGAGGAGT-3' and probe, 5'Fam-ATTCCACGCCCAGCTACCCAATGG CCT-3'Tamra; Twist forward, 5'-CCCTCGGACAAGCTG 
AGCAA-3', reverse, 5'-TCGCTCTGGAGGACCTGGTA-3' and probe, 5'Fam-ATTCAGACCCTCAAGCTGGCGGCC A-3'Tamra; vimentin forward, 5'-CAATGAGTCCCTGGA ACGCC-3', reverse, 5'-GGTGACGAGCCATTTCCTCC-3' and probe, 5'Fam-ACCAAGACACTATTGGCCGCCTGC AGG-3'Tamra; GAPDH forward, 5'-ATCATCCCTGCCT CT ACTGG-3', reverse, 5'-GTCAGGTCCACCACTGACAC-3' and probe, 5'Fam-ACCTTGCCCACAGCCTTGGC-3'Tamra; The relative mRNA expression levels were calculated using $2^{-\Delta \Delta C q}$ method (21).

Western blotting. Cells were lysed using RIPA Lysis Buffer (Beyotime Institute of Biotechnology). The protein concentrations were determined using the bicinchoninic acid (BCA) assay. Proteins were separated via $12 \%$ SDS-PAGE and blocked with $5 \%$ bovine serum albumin at $4^{\circ} \mathrm{C}$ overnight. A total of $20 \mathrm{ml}$ of $12 \%$ separation gel was prepared, and the $5 \%$ stacking gel was added on top of the separation gel. In total, 20-40 $\mu \mathrm{l}$ protein samples with $5 \mu \mathrm{l}$ protein marker were added to the corresponding lanes. Then the protein samples were transferred to the cellulose nitrate membranes by electrophoresis. The cellulose nitrate membranes were incubated with the following primary antibodies at $4^{\circ} \mathrm{C}$ overnight: Anti-c-Myc (product code ab32072; 1:2,000), anti-cyclin D1 (product code ab16663; 1:2,000), anti-Slug (product code ab51772; 1:2,000), anti-Twist (product code ab50887; 1:2,000), anti-E-cadherin (product code ab40772; 1:2,000), anti-N-cadherin (product code ab76011; 1:2,000), anti-vimentin (product code ab92547; 1:2,000), anti-Sox 2 (product code ab92494; 1:2,000), anti-Oct4 (product code ab200834; 1:2,000), anti-KLF4 (product code ab215036; 1:2,000), anti-ALDH1 (product code ab177463; 1:2,000), anti-CD44 (product code ab189524; 1:2,000), anti-phosphorylated (p)- $\beta$-catenin (product code ab81305; $1: 2,000$ ) and anti-ROR $\beta$ antibody (product code ab228650; 1:1,000; all from Epitomics; Abcam), anti-Bcl-2 like protein 11 (BCL2L11; cat. no. AP8553c; 1:1,000; Abgent, Inc.) and anti-GAPDH (cat. no. KC-5G5; 1:5,000; KangChen Biotech Co., Ltd.). Then the cellulose nitrate membranes were incubated with the secondary antibodies at room temperature for $1 \mathrm{~h}$ : Goat anti-rabbit IgG H\&L (HRP) (product code ab6721; 1:2,000) or goat anti-mouse IgG H\&L (HRP) (product code ab6789; 1:2,000; both from Epitomics; Abcam). Protein bands were visualized with ECL reagent (PerkinElmer, Inc.), according to the manufacturer's protocol. BandScan software (V5.0; Glyko Biomedical, Ltd.) was used for densitometric analysis.

Gene chip detection and Gene Ontology (GO) analysis. GC cells overexpressing ROR $\beta$ were lysed by $1 \mathrm{ml}$ TRIzol reagent (Sangon Biotech, Co., Ltd.) and total RNA was extracted using PrimeScript RT reagent Kit gDNAEraser (cat. no. RR047A; Takara Bio, Inc.) according to the manufacturer's instructions. A GeneChip (HTA 2.0; Affymetrix; Thermo Fisher Scientific, Inc.) was used to identify differentially expressed mRNAs. Then 460 differentially expressed genes in the Genechip were imputed into DAVID (http://david.abcc.ncifcrf,gov/home.jsp) to perform the GO analysis (22).

Gene Set Enrichment Analysis (GSEA). All 200 mRNA GeneChip databases containing patients with GC were obtained from the City of Hope National Medical Center,
Los Angeles, USA. GSEA (23) was used to analyze the association between ROR $\beta$ expression levels and GCSC markers.

Top/Fop luciferase reporter assay. ROR $\beta$-overexpression GC cells were seeded into 6-well plates at a density of $1 \times 10^{6}$ at $37^{\circ} \mathrm{C}$ with $5 \% \mathrm{CO}_{2}$ for $24 \mathrm{~h}$. A total of $8 \mu \mathrm{l}$ Fugene 6 (Roche Diagnostics) was incubated with $100 \mu \mathrm{l}$ OPTI-MEM (Invitrogen; Thermo Fisher Scientific, Inc.) at room temperature for $5 \mathrm{~min}$. Then, a total of $2 \mu \mathrm{g}$ plasmid mixture including TOP (MilliporeSigma), FOP (MilliporeSigma) and PRL (Promega Corporation) (4:4:1) were added to the aforementioned mixture and incubated at room temperature for $15 \mathrm{~min}$. Then the mixture of Fugene 6 and plasmids were added to the 6-well plate and mixed, and incubated at $37^{\circ} \mathrm{C}$ in a $5 \% \mathrm{CO}_{2}$ incubator for $24 \mathrm{~h}$. The cell lysates were transferred to the centrifuge tube after cell lysis. GloMax 20/20 Luminometer was used to detect the fluorescence activity. A total of $20 \mu \mathrm{l}$ of the aforementioned cell lysates were added with $100 \mu 1$ of LAR II. After mixing, firefly luciferase activity was detected. Then $100 \mu \mathrm{l}$ Stop\&Glo Reagent was added to detect Renilla luciferase activity. The Dual-Luciferase ${ }^{\circledR}$ Reporter $\left(\mathrm{DLR}^{\mathrm{TM}}\right)$ Assay System (Promega Corporation) was used.

Statistical analysis. Statistical analysis was performed using SPSS 19.0 software (IBM Corp.). Statistical differences between groups were performed using one way ANOVA (with least significant difference test or Tamhane's T2 post hoc test) or unpaired Student's t-test. $\mathrm{P}<0.05$ was considered to indicate a statistically significant difference. All data are presented as the mean \pm SD of triplicate experiments.

\section{Results}

Expression levels of ROR $\beta$ are downregulated in GC. ROR $\beta$ was previously reported to be expressed in the CNS (24); however, the expression levels of ROR $\beta$ in GC cells remain unknown. As demonstrated in Fig. 1A, ROR $\beta$ was expressed in the two GC cell lines, MKN45 and AGS. AGS cells were subsequently transfected with the ROR $\beta$-pEGFP-C1 plasmid and western blotting was used for confirmation (Fig. 1B). The nuclear localization of ROR $\beta$ was further confirmed using western blotting following nuclear/cytosolic fractionation (Fig. 1C). IHC staining of clinical GC specimens revealed that the expression levels of ROR $\beta$ were significantly downregulated in GC tissues compared with para-carcinoma tissues (Fig. 1D). RT-qPCR analysis further determined that ROR $\beta$ expression levels were downregulated in GC tissues (Fig. 1E). These results indicated that ROR $\beta$ expression levels may be downregulated during GC development.

ROR $\beta$ expression levels are inversely associated with GCSC markers. The mRNA expression levels of ROR $\beta$ in $200 \mathrm{GC}$ tissues were divided into two groups: ROR $\beta$ high $\left(\operatorname{ROR} \beta^{\text {high }}\right)$ and low $\left(\mathrm{ROR} \beta^{\text {low }}\right)$ expression groups. Differentially expressed genes were identified using GSEA. The results revealed that the expression levels of CSC markers, including ALDH1, CD44 and activated leukocyte cell adhesion molecule (ALCAM)/CD166, were all downregulated in the ROR $\beta^{\text {high }}$ cohort compared with the ROR $\beta^{\text {low }}$ cohort (Fig. $2 \mathrm{~A}$ and B). These results indicated that ROR $\beta$ may be a cell differentiation inducer. 

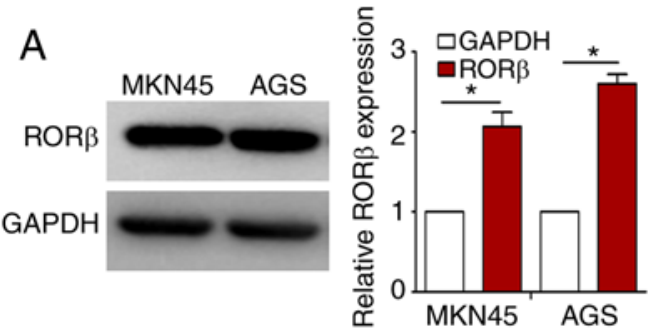

D

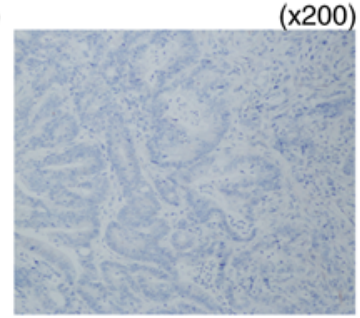

Tumor (x200)

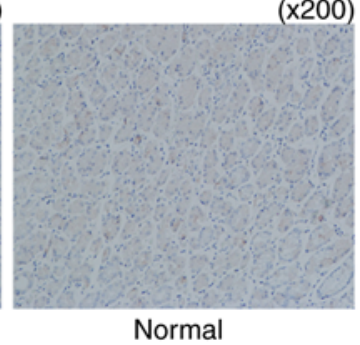

B
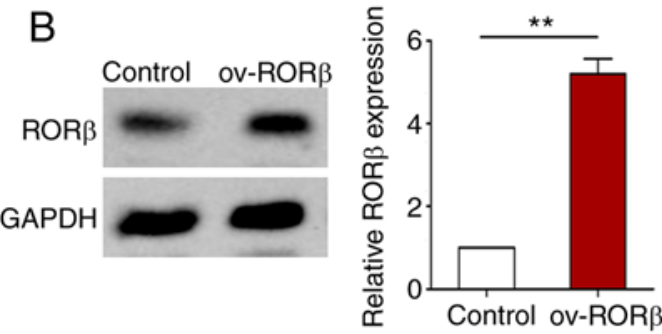

E
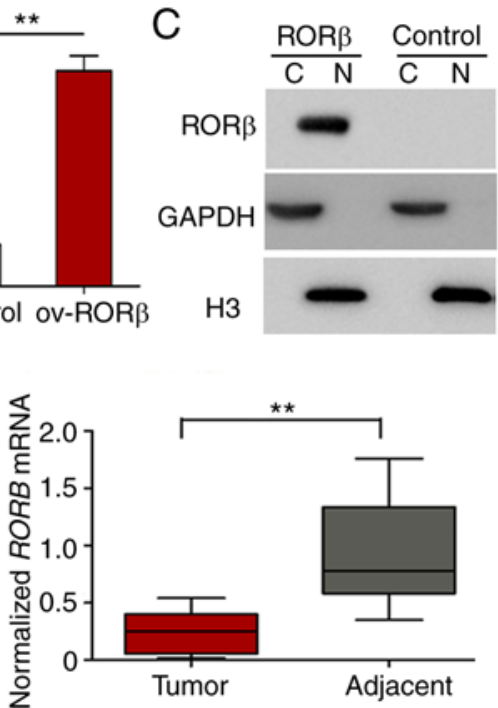

Figure 1. Expression levels of ROR $\beta$ in GC cells. (A) ROR $\beta$ expression levels in GC cells were analyzed using western blotting. (B) Overexpression of ROR $\beta$ in AGS cells was examined using western blotting. (C) AGS cells were subjected to nuclear/cytosolic fractionation, and ROR $\beta$ expression levels were analyzed using western blotting. (D) ROR $\beta$ expression levels in GC tissues were analyzed using immunohistochemical staining. (E) mRNA expression levels of ROR $\beta$ were analyzed in GC tissues using reverse transcription-quantitative PCR. Data were analyzed using a Student's t-test. " $\mathrm{P}<0.05$ and ${ }^{* *} \mathrm{P}<0.01$. ROR $\beta$, retinoic acid-related orphan receptor $\beta ; \mathrm{GC}$, gastric cancer; ov-, overexpression.
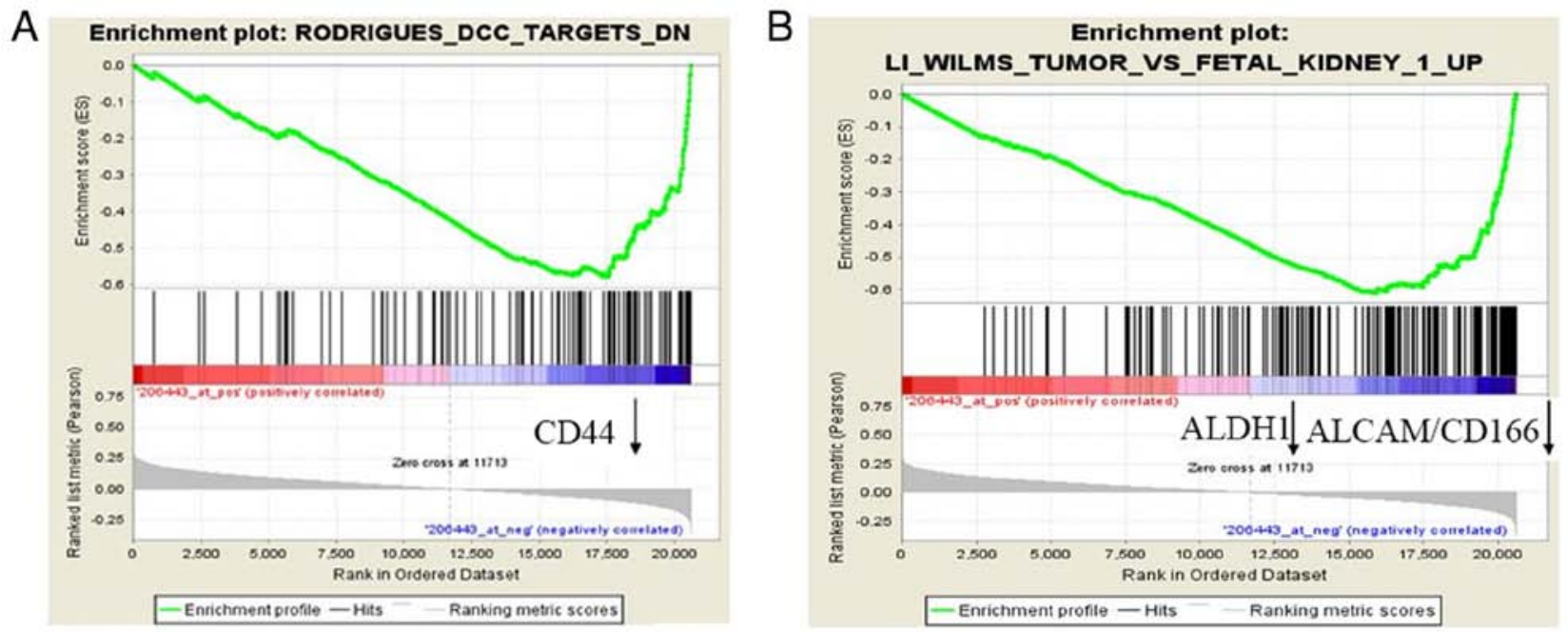

Figure 2. GSEA of ROR $\beta$ in GC. Differential ROR $\beta$ expression ( $n=200)$ in GC tissues was analyzed using GSEA. The mRNA expression levels of CD44, ALDH1 and ALCAM/CD166 were compared between the ROR $\beta^{\text {high }}$ and ROR $\beta^{\text {low }}$ cohorts. GSEA, Gene Set Enrichment Analysis; ROR $\beta$, retinoic acid-related orphan receptor $\beta$; GC, gastric cancer; ALDH1, aldehyde dehydrogenase 1; ALCAM, activated leukocyte cell adhesion molecule.

ROR $\beta$ induces growth inhibition and apoptosis in GC cells. To determine the functional impact of ROR $\beta$ on GC cells, a CCK-8 assay was performed. The viability of GC cells was significantly inhibited following the overexpression of ROR $\beta$ (Fig. 3A). Conversely, the percentages of Annexin V-positive and PI-positive apoptotic GC cells were significantly increased in GC cells overexpressing ROR $\beta$ (Fig. 3B and C). Subsequently, the changes in the expression levels of genes between control and ROR $\beta$-overexpressing AGS cells were analyzed using GeneChip. The results revealed that BCL2L11, a pro-apoptotic gene, was the most significantly upregulated gene in cells overexpressing ROR $\beta$, which was further verified using western blotting (Fig. 3D and E). In addition, GO analysis discovered that
ROR $\beta$ was mainly involved in 'nucleoside', 'nucleotide', 'nucleic acid metabolism and mRNA transcription', 'cell cycle', 'cell proliferation and differentiation' and 'tumor formation' (data not shown). These results indicated that ROR $\beta$ may inhibit viability, but trigger BCL2L11-dependent apoptosis in GC cells.

ROR $\beta$ confers resistance to EMT in GC cells. Previous studies have reported that EMT may be related to the stemness of CSCs (25-27). Therefore, whether ROR $\beta$ played a role in modulating the metastatic ability of GC cells was investigated. The results of the wound healing assay demonstrated that the migratory ability was decreased in GC cells overexpressing ROR $\beta$ compared with control cells (Fig. 4A). 

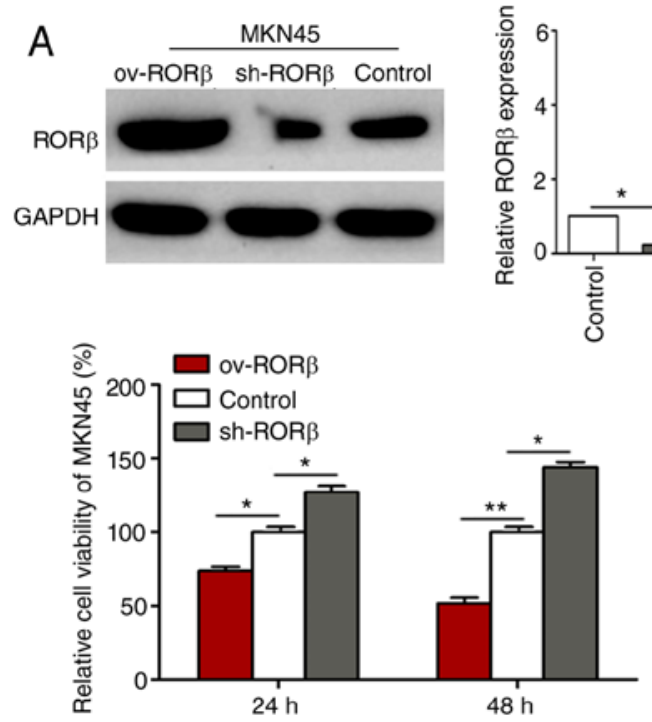

$\mathrm{B}$
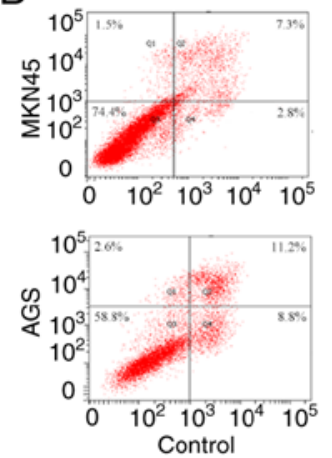

D

\begin{tabular}{lll}
\hline Probeset ID & Gene symbol & Ratio \\
\hline 11736952_a_at & RORB & 17.5854 \\
11753863_s_at & BCL2L11 & 5.08522 \\
11760319_at & HBP1 & 4.69933 \\
1174102_a_at & SC4MOL & 4.6492 \\
11745162_s_at & BCL2L11 & 4.56658 \\
11745723_s_at & MALAT1 & 4.34277 \\
11746573_s_at & RHOB & 4.04464 \\
\hline
\end{tabular}
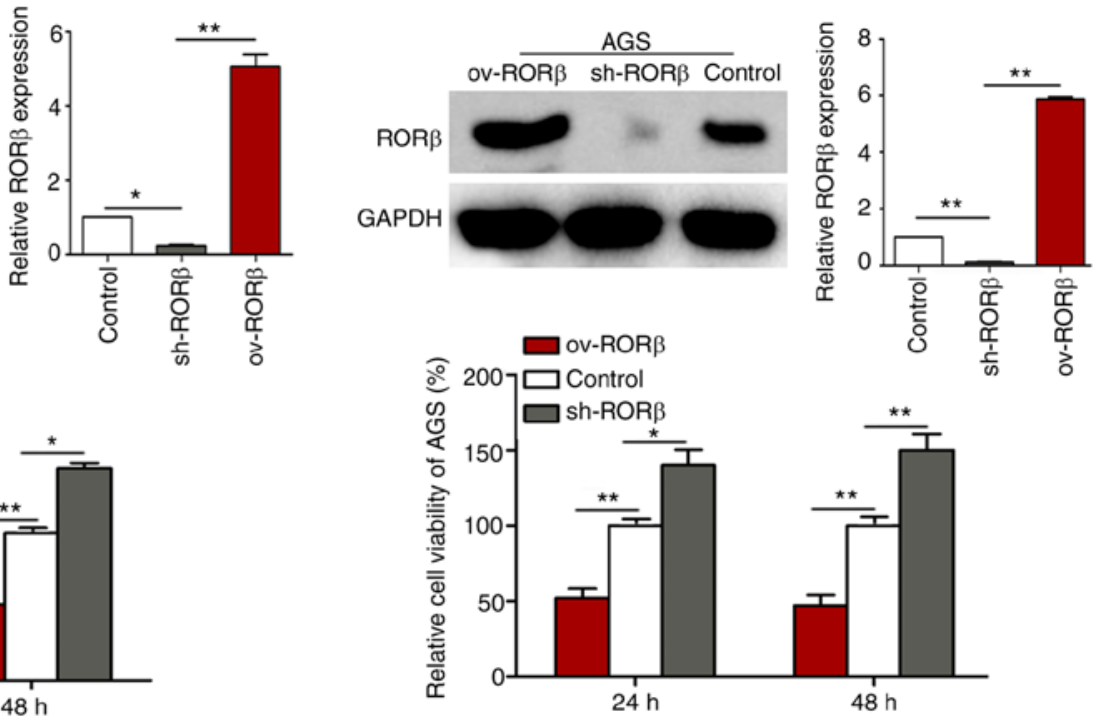

C

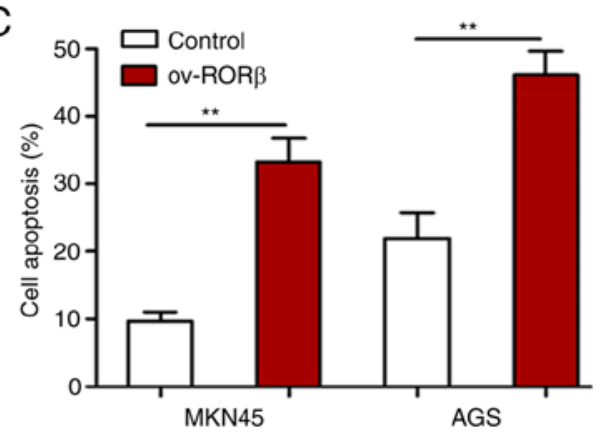

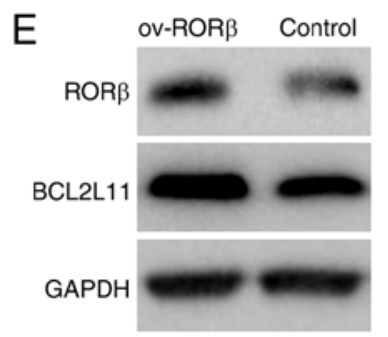
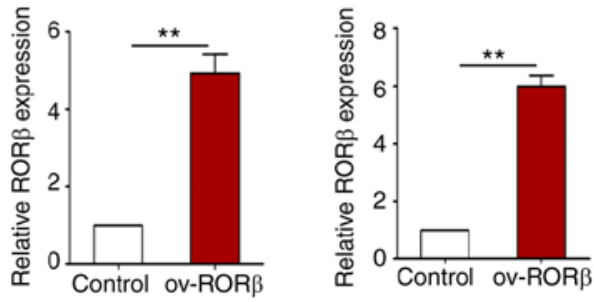

Figure 3. ROR $\beta$ exerts anti-proliferative and pro-apoptotic effects on GC cells. (A) MKN45 and AGS cells were transfected with control, ROR $\beta$ overexpression vector or ROR $\beta$ shRNA and confirmed by western blotting. The viability of GC cells was evaluated using an CCK- 8 assay. Data were analyzed using one-way ANOVA. (B and C) Apoptosis of GC cells was detected using flow cytometry. GC cells were transfected with control or ROR $\beta$-overexpression vector for 24 h. Cell apoptosis was evaluated using the values in quadrants 2 and 4. Data were analyzed using a unpaired Student's t-test. (D) GeneChip was used to evaluate the gene expression profiles. The top differentially expressed genes are listed. (E) Protein expression levels of BCL2L11 were analyzed using western blotting. ${ }^{*} \mathrm{P}<0.05$ and ${ }^{* *} \mathrm{P}<0.01$. ROR $\beta$, retinoic acid-related orphan receptor $\beta$; GC, gastric cancer; sh-, short hairpin; BCL2L11, Bcl-2 like protein 11; ov, overexpression.

Immunofluorescence staining of F-actin revealed a downregulated fluorescence signal in ROR $\beta$ overexpression GC cells, which indicated ROR $\beta$ overexpression inhibited F-actin polymerization and arrangement (Fig. 4B). Consistent with the increased cell migratory ability, ROR $\beta$ overexpression downregulated the expression levels of EMT-related factors (Slug, Twist and $\mathrm{N}$-cadherin) and upregulated the expression levels of E-cadherin (Fig. 4C). These findings indicated that ROR $\beta$ may suppress EMT in GC cells.

ROR $\beta$ decreases the stemness of GCSCs. As an inverse association was identified between ROR $\beta$ expression levels and several GCSC markers, it was subsequently investigated whether ROR $\beta$ was able to affect the stemness of GCSCs. The results demonstrated that the sphere forming ability was significantly decreased in GC cells following ROR $\beta$ overexpression, while the genetic silencing of ROR $\beta$ using shRNA caused the opposite effect, indicating the inhibitory role of ROR $\beta$ on cell stemness (Fig. 5A). Similarly, the expression levels of iPS cell-related factors (Sox2, Oct4 and KLF4) were downregulated in GC cells overexpressing ROR $\beta$ and upregulated in GC cells following the knockdown of ROR $\beta$, which was further verified using western blotting (Fig. 5B and C). ROR $\beta$-overexpressing AGS cells were subsequently inoculated into nude mice to evaluate the effect on the tumorigenic capacity and stemness of GC cells in vivo. The nude mice were inoculated with ROR $\beta$ overexpression GC cells and control cells (at the density of $1 \times 10^{5}, 5 \times 10^{5}$ and $1 \times 10^{6}$ ) cells. At the fourth week, there was no significant difference in the tumor-forming rate of the third group (at the density of $1 \times 10^{6}$ ), while there were significant differences in 
A
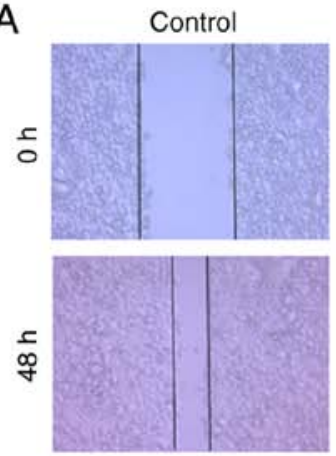

MKN45
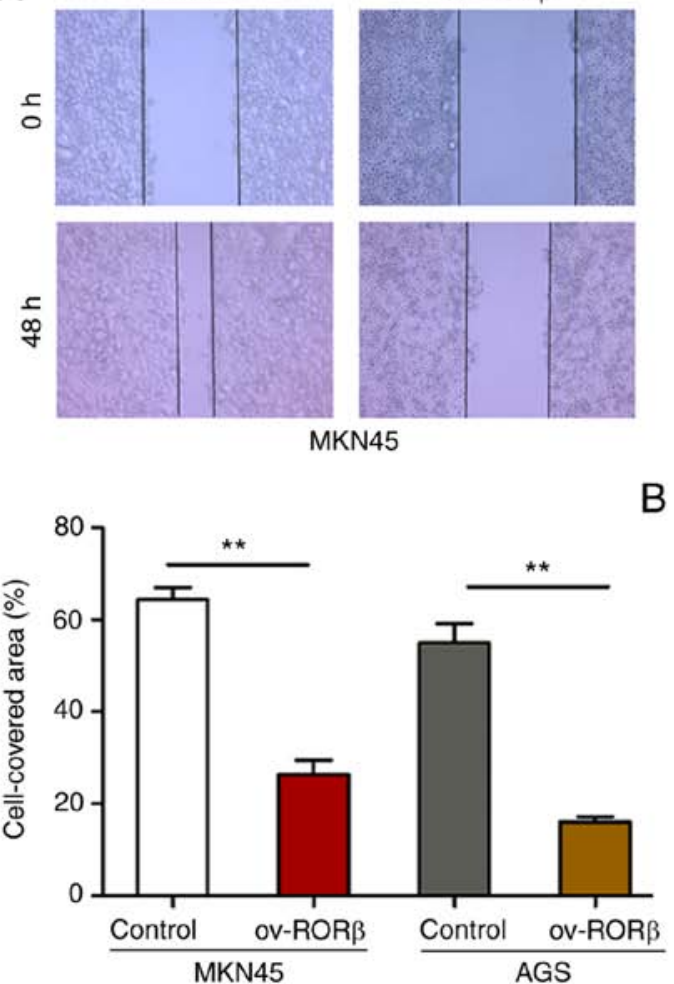
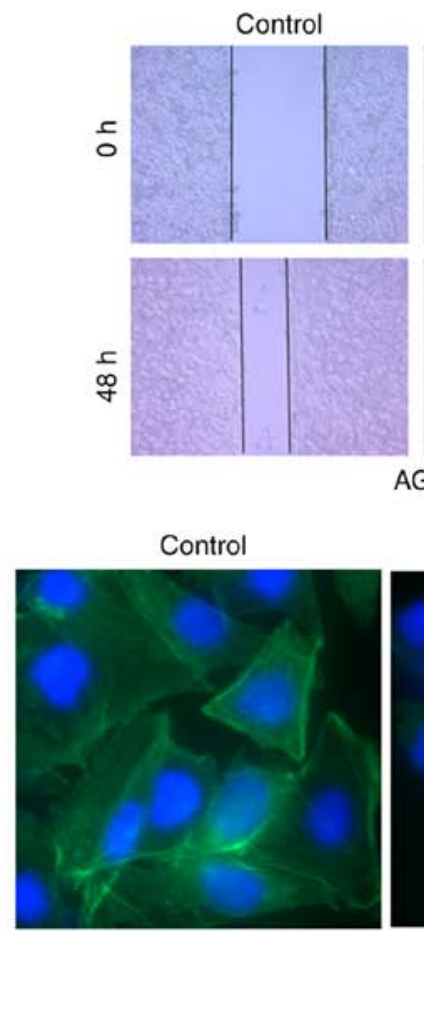

AGS
ov-ROR $\beta$
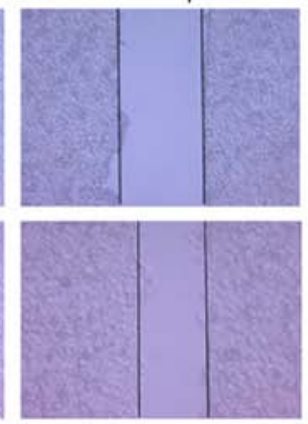

Ov-RORB
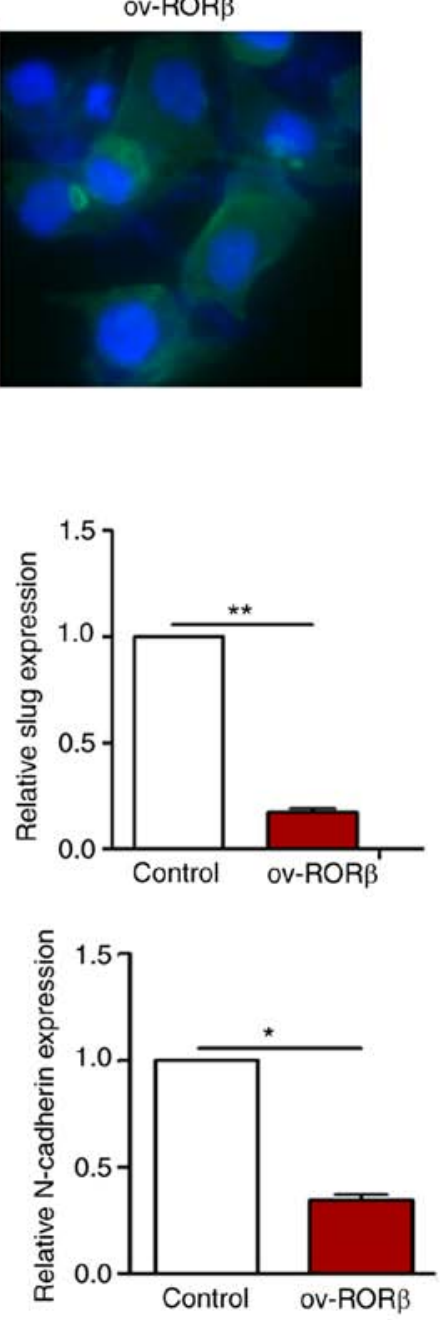

Figure 4. ROR $\beta$ inhibits EMT in GC cells. GC cells were transfected with control or ROR $\beta$ overexpression vector. (A) Cell migration was measured using a wound healing assay. ${ }^{* *} \mathrm{P}<0.01$. (B) Cytoskeleton rearrangement in the control and ROR $\beta$-overexpressing AGS cells was revealed by immunofluorescence staining of FITC-phalloidin and DAPI (x400). (C) Western blotting was performed to analyze the expression levels of EMT-related factors. * $<0.05$ and ${ }^{* *} \mathrm{P}<0.01$. ROR $\beta$, retinoic acid-related orphan receptor $\beta$; EMT, epithelial-mesenchymal transition; GC, gastric cancer; ov, overexpression.

the tumor-forming rate of the first (at the density of $1 \times 10^{5}$ ) and second groups (at the density of $5 \times 10^{5}$ ) (Fig. 5D). As shown in Fig. 5E-G, ROR $\beta$ overexpression markedly inhibited the tumor growth of GC cells and downregulated the expression of EMT factors and GCSC markers of tumors in mice. These results indicated that ROR $\beta$ may disrupt the stemness of GCSCs.

ROR $\beta$ negatively regulates the activity of the Wnt signaling pathway. Finally, the molecular mechanisms underlying the suppressive effect of ROR $\beta$ on GCSCs were investigated. As a well-characterized oncogenic pathway, the abnormal activation of the Wnt signaling pathway has been implicated in the stemness maintenance of CSCs (13). The expression levels of c-Myc, cyclin D1 and p- $\beta$-catenin, two target genes downstream of the Wnt signaling pathway (28), were significantly downregulated in GC cells overexpressing ROR $\beta$ (Fig. 6A). The results of the luciferase reporter assay revealed that the overexpression of $\mathrm{ROR} \beta$ 
A

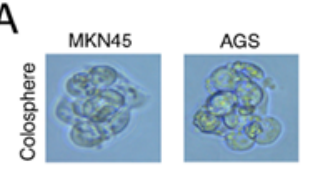

$\mathrm{B}$

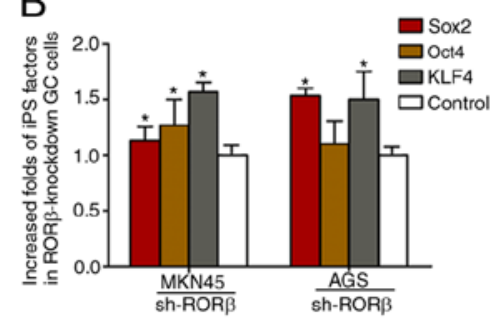

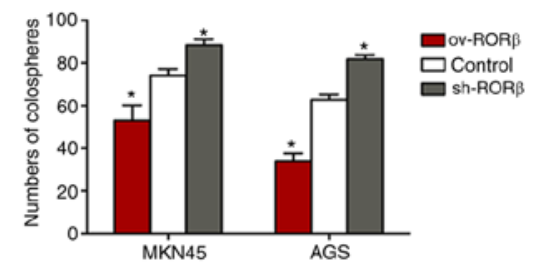

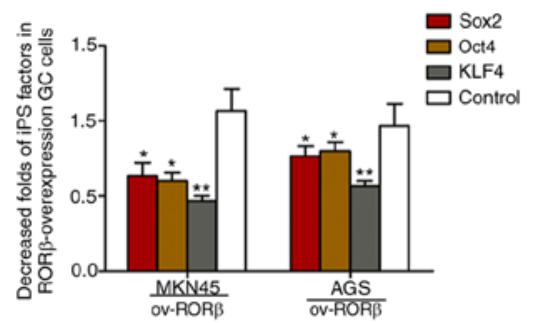

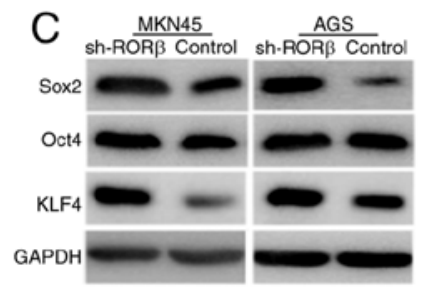
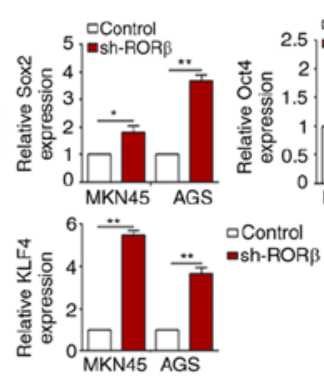

$\mathrm{E}$

D

\begin{tabular}{lccc}
\multicolumn{4}{c}{ Tumorigenesis in vivo } \\
\hline Cells $\left(10^{5}\right)$ & 1 & 5 & 10 \\
\hline ROR $\beta$ & $0 / 5$ & $2 / 5$ & $5 / 5$ \\
\hline Control & $4 / 5$ & $5 / 5$ & $5 / 5$ \\
\hline
\end{tabular}

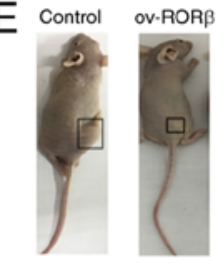

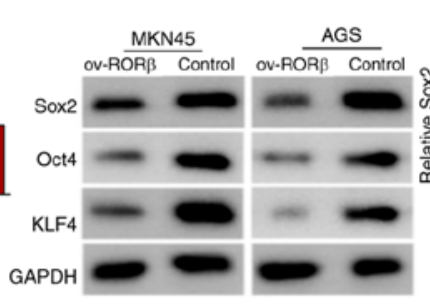
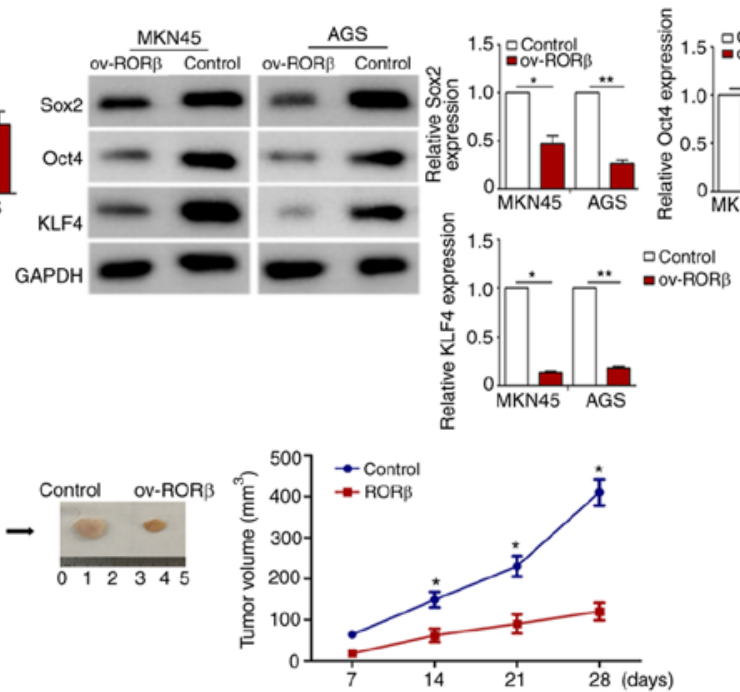
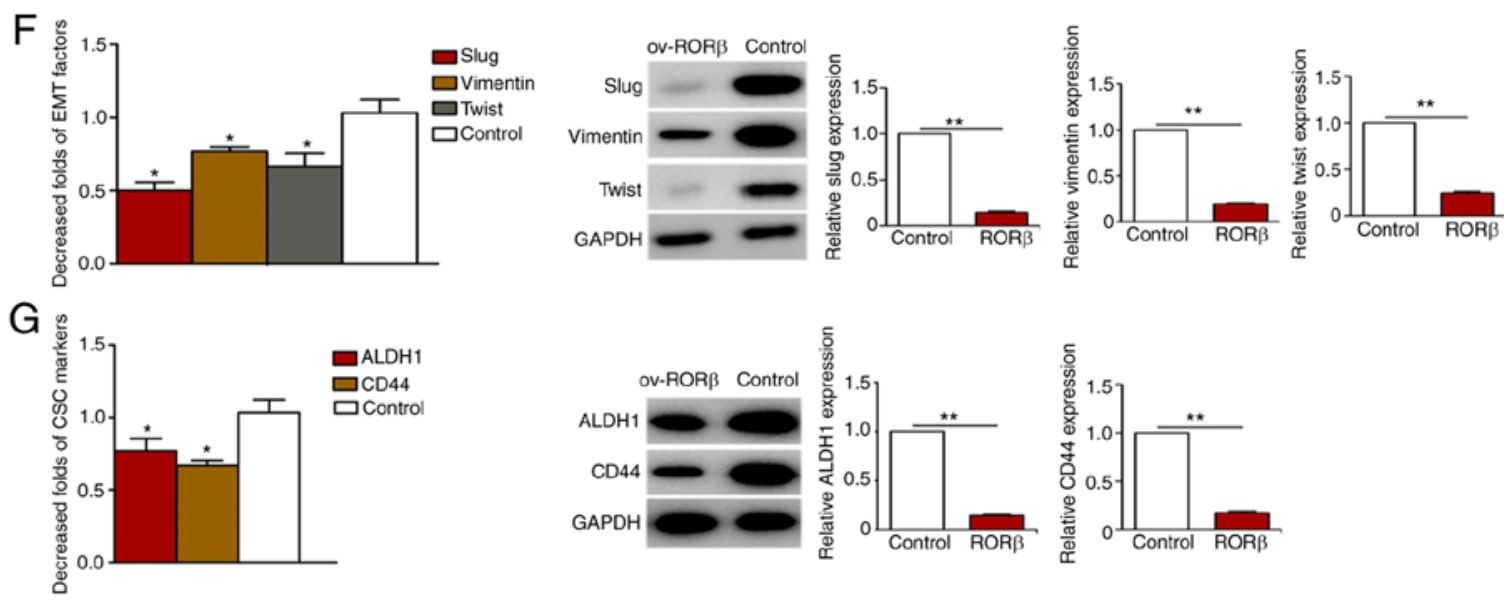

Figure 5. ROR $\beta$ inhibits stemness properties of GCSCs. GC cells were transfected with control, ROR $\beta$ overexpression vector or ROR $\beta$ shRNA vector. (A) Images of colospheres of GC cells. Self-renewal capacity of GCSCs was determined using a sphere formation assay. (B and C) mRNA expression levels of CSC markers in ROR $\beta$-overexpressing or ROR $\beta$-silenced AGS cells and MKN45 cells were analyzed using RT-qPCR and confirmed by western blotting. (D and E) Tumorigenicity of ROR $\beta$-overexpressing cells. Nude mice were inoculated with $1 \times 10^{5}, 5 \times 10^{5}$ and $1 \times 10^{6}$ ROR $\beta$-overexpressing AGS cells ( $\mathrm{n}=5$ ). The numbers and volumes of the tumors were observed within 4 weeks. (F) RNA and proteins from the tumors were extracted. Expression levels of EMT markers in the aforementioned tumors were analyzed using RT-qPCR and western blotting. (G) RNA and proteins from the tumors were extracted. Expression levels of GCSC markers in the aforementioned tumors were analyzed using RT-qPCR and western blotting. Data were analyzed using a unpaired Student's t-test. ${ }^{*} \mathrm{P}<0.05$ and ${ }^{* *} \mathrm{P}<0.01$. ROR $\beta$, retinoic acid-related orphan receptor $\beta$; GCSCs, GC stem cells; GC, gastric cancer; CSCs, cancer stem cells; RT-qPCR, reverse transcription-quantitative PCR; ov, overexpression; sh-, short hairpin.

significantly reduced the Top/Fop luciferase activity in GC cells (Fig. 6B). These findings suggested that ROR $\beta$ may impair the stemness of GCSCs by hindering Wnt $/ \beta$-catenin signaling.

\section{Discussion}

It is widely acknowledged that CSCs, a small group of cells with self-renewal and strong tumorigenic properties, serve 

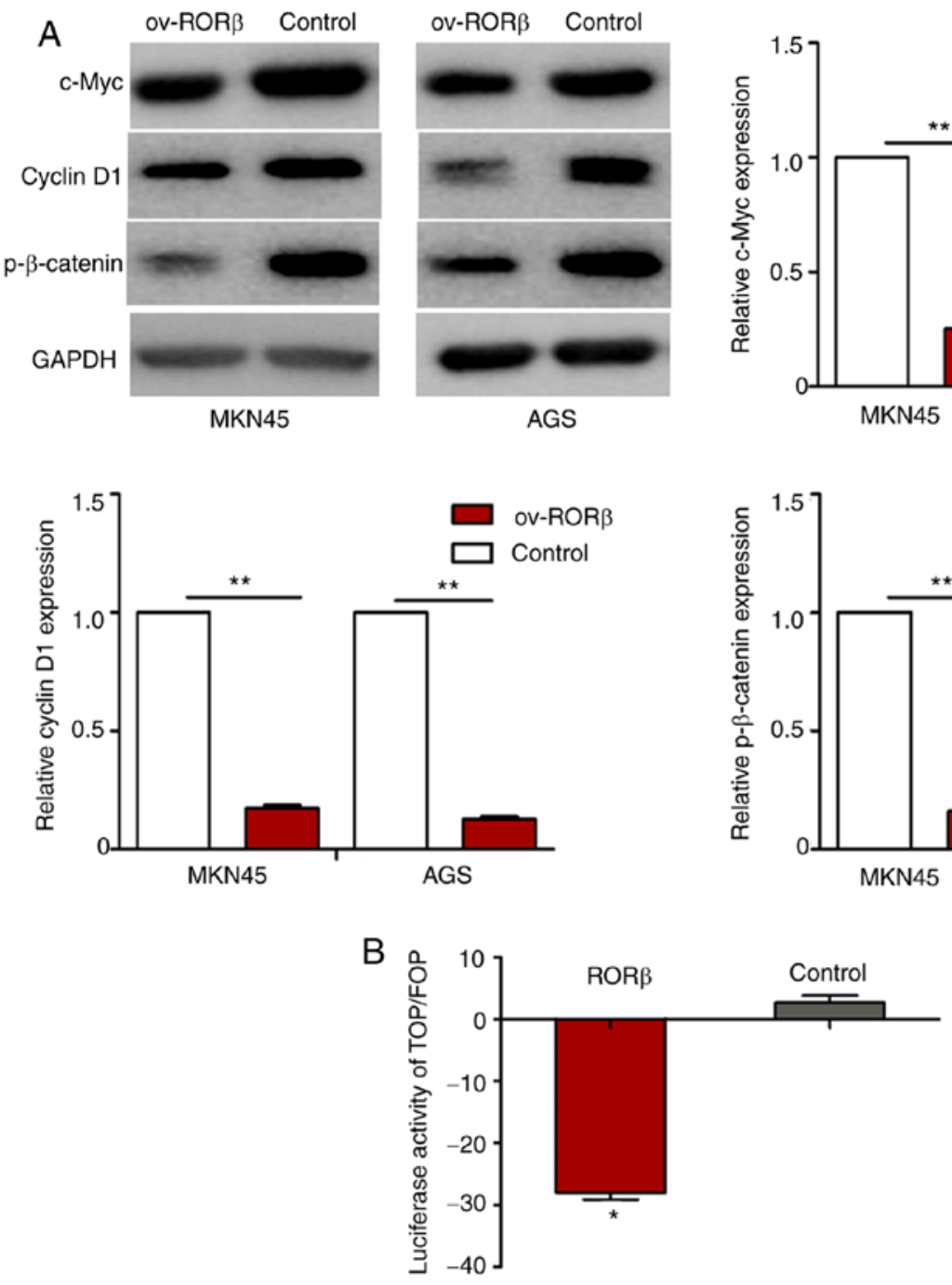

Figure 6. ROR $\beta$ inhibits the Wnt/ $\beta$-catenin signaling pathway in GC stem cells. MKN45 and AGS cells were transfected with control or ROR $\beta$ overexpression vector. (A) Expression levels of c-Myc, cyclin D1 and p- $\beta$-catenin were analyzed using western blotting. ${ }^{* *} \mathrm{P}<0.01$. (B) ROR $\beta$-overexpressing GC cells and control cells were transfected with the Top/Fop luciferase reporter. The luciferase activity was measured following 24 h. ${ }^{*} \mathrm{P}<0.05$. ROR $\beta$, retinoic acid-related orphan receptor $\beta$; GC, gastric cancer; ov, overexpression; p-, phosphorylated.

important roles in tumorigenesis, metastasis, recurrence and chemoradiotherapy resistance $(29,30)$. GCSCs were first identified by Yang et al (7). Since this discovery, further studies have identified the presence of GCSCs (8-11). However, the mechanisms of GCSCs remain unknown. ROR $\beta$ was firstly identified to be expressed in GC in the present study, where it served as a novel inhibitor of EMT and CSC properties by downregulating the Wnt signaling pathway.

$\mathrm{ROR} \beta$ is a member of the orphan nuclear receptor family. ROR $\beta$ was previously considered to be only expressed in the CNS (15); however, accumulating studies have reported that $\operatorname{ROR} \beta$ is also localized in various other systems such as bone tissue, pancreatic cancer tissue and colorectal cancer tissue $(16,17)$, where it participated in physiological functions, such as regulating bone formation and the circadian rhythm. In addition, $\operatorname{ROR} \beta$ was demonstrated to be involved in the development of numerous types of cancer (15). To date, to the best of our knowledge, there are no current previous studies reporting the biological function of ROR $\beta$ in GC. The present study was the first to reveal that the expression levels of ROR $\beta$ were significantly downregulated in GC, suggesting that
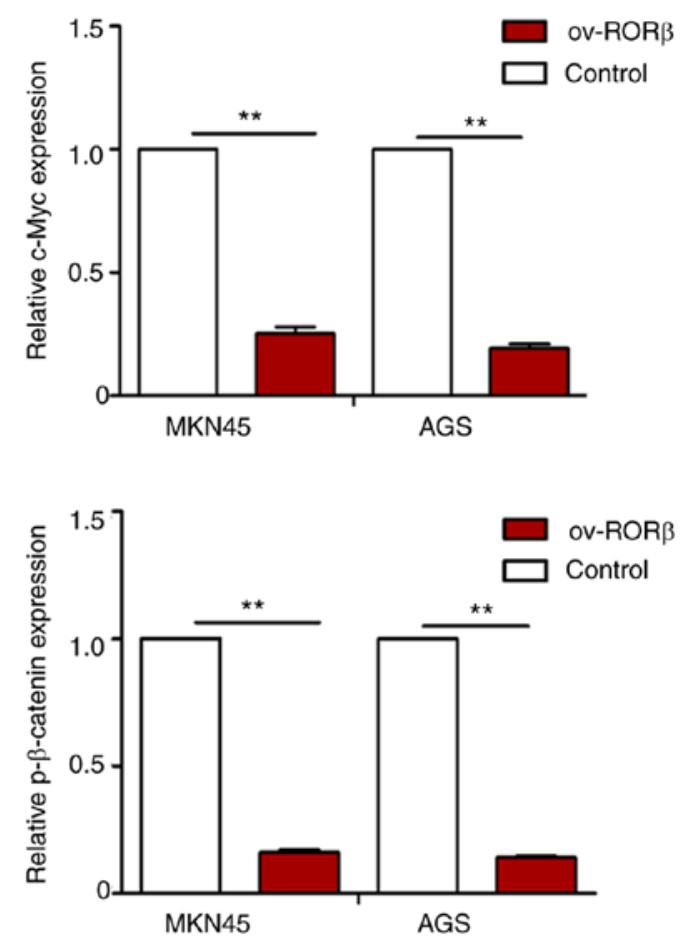

ROR $\beta$ may serve as a tumor suppressor. Through GSEA, the expression levels of stem cell surface markers were discovered to be downregulated in tissues with upregulated expression levels of ROR $\beta$ compared with control tissues, suggesting that $\operatorname{ROR} \beta$ may be a cell differentiation inducer.

In the present study, ROR $\beta$ inhibited GC cell viability, as determined by a CCK- 8 assay. GeneChip-scanning experiments have previously reported that BCL2L11, a pro-apoptotic protein, mainly functioned by inhibiting Bcl-2-induced apoptosis and inactivating the expression levels of Bax and Bak (31). Therefore, it was hypothesized that ROR $\beta$ may promote the apoptosis of $\mathrm{GC}$ cells. The results of GO analysis indicated that $\mathrm{ROR} \beta$, as a transcription factor, may also be involved in tumorigenesis, regulating the cell cycle, cell proliferation and differentiation. In addition, the overexpression of ROR $\beta$ in GC cells decreased the $\mathrm{GC}$ cells stemness by downregulating the expression levels of CSC surface markers, inhibiting the sphere forming ability, decreasing the tumor growth rate and downregulating the expression levels of EMT-related factors. These findings strongly indicated that $\operatorname{ROR} \beta$ may regulate the occurrence and development of GC by inhibiting the stemness of CSCs. 
Previous studies have reported that the Wnt signaling pathway is an important regulatory pathway in GCSCs $(31,32)$. Tan et al (33) revealed that CSCs in the AQP5 ${ }^{+}$tissues promoted GC in vivo by activating the Wnt signaling pathway in newly generated AQP5-creERT2 model mice. In the present study, ROR $\beta$ downregulated the expression levels of downstream molecules of the Wnt signaling pathway in GCSCs, which suggested that ROR $\beta$ regulated the stemness of GCSCs by downregulating the activity of the Wnt signaling pathway. Therefore, $\operatorname{ROR} \beta$, as a Wnt inhibitor, may represent a novel therapy to reduce CSC activity in GC cases with upregulated expression levels of ROR $\beta$.

In conclusion, the findings of the present study revealed that ROR $\beta$ significantly inhibited the stemness properties of GC cells by downregulating the Wnt signaling pathway. Therefore, $\operatorname{ROR} \beta$ may represent a potential novel antitumor agent for the treatment of GC. However, the downstream target molecule of ROR $\beta$ as an antitumor agent for the treatment of GC needs to be further clarified in the future.

\section{Acknowledgements}

Not applicable.

\section{Funding}

The present study was financially supported by the Zhejiang Provincial Medical and Health science Foundation (grant nos. 2021441200, 2015KYB020 and 2020380312), the National Science of Foundation Committee of China (grant no. 81602586) and the Zhejiang Provincial Traditional Chinese Medicine Science Research Foundation (grant no. 2015ZA010).

\section{Availability of data and materials}

All datasets generated and analyzed during the present study are available from the corresponding author on reasonable request.

\section{Authors' contributions}

ZW, MC and WG conceived and designed the study. PD, $\mathrm{KG}$ and YF performed the statistical analysis. MG and QW performed the experiments. All authors read and approved the final manuscript.

\section{Ethics approval and consent to participate}

All animal experiments were approved by the Institutional Animal Care and Use Committee of Zhejiang University (Hangzhou, China) and complied with the Animal Welfare Act to euthanize all animals in the experiment. GC tissues were collected at the Sir Run Run Shaw Hospital of the Zhejiang University following ethical approval from the Institutional Review Board from Sir Run Run Shaw Hospital (Hangzhou, China). All patients provided written informed consent.

\section{Patient consent for publication}

Not applicable.

\section{Competing interests}

The authors declare that they have no competing interests.

\section{References}

1. Torre LA, Bray F, Siegel RL, Ferlay J, Lortet-Tieulent J and Jemal A: Global cancer statistics. CA Cancer J Clin 65: 87-108, 2015.

2. Mariette C, Renaud F, Piessen G, Gele P, Copin MC, Leteurtre E, Delaeter C, Dib M, Clisant S, Harter V, et al: The FREGAT biobank: A Clinico-biological database dedicated to esophageal and gastric cancers. BMC Cancer 18: 139, 2018.

3. Pan Y, Ma S, Cao K, Zhou S, Zhao A, Li M, Qian F and Zhu C: Therapeutic approaches targeting cancer stem cells. J Cancer Res Ther 14: 1469-1475, 2018.

4. Taniguchi H, Moriya C, Igarashi H, Saitoh A, Yamamoto H, Adachi Y and Imai K: Cancer stem cells in human gastrointestinal cancer. Cancer Sci 107: 1556-1562, 2016.

5. Guo Y, Feng K, Wang Y and Han W: Targeting cancer stem cells by using chimeric antigen receptor-modified T cells: A potential and curable approach for cancer treatment. Protein Cell 9: 516-526, 2018.

6. Yang Y, Wu KE, Zhao E, Li W, Shi L, Xie G, Jiang B, Wang Y, Li R, Zhang P, et al: B7-H1 enhances proliferation ability of gastric cancer stem-like cells as a receptor. Oncol Lett 9: 1833-1838, 2015.

7. Yang YC, Wang SW, Hung HY, Chang CC, Wu IC, Huang YL, Lin TM, Tsai JL, Chen A, Kuo FC, et al: Isolation and characterization of human gastric cell lines with stem cell phenotypes. J Gastroenterol Hepatol 22: 1460-1468, 2007.

8. Bekaii-Saab T and El-Rayes B: Identifying and targeting cancer stem cells in the treatment of gastric cancer. Cancer 123: 1303-1312, 2017.

9. Nguyen PH, Giraud J, Chambonnier L, Dubus P, Wittkop L, Belleannée G, Collet D, Soubeyran I, Evrard S, Rousseau B, et al: Characterization of biomarkers of tumorigenic and chemoresistant cancer stem cells in human gastric carcinoma. Clin Cancer Res 23: 1586-1597, 2017.

10. Gong X, Azhdarinia A, Ghosh SC, Xiong W, An ZQ, Liu QY and Carmon KS: LGR5-targeted antibody-drug conjugate eradicates gastrointestinal tumors and prevents recurrence. Mol Cancer Ther 15: 1580-1590, 2016.

11. Nguyen PH, Giraud J, Staedel C, Chambonnier L, Dubus P, Chevret E, Bœuf H, Gauthereau X, Rousseau B, Fevre M, et al: All-trans retinoic acid targets gastric cancer stem cells and inhibits patient-derived gastric carcinoma tumor growth. Oncogene 35: 5619-5628, 2016.

12. Fu Y, Du PZ, Zhao J, Hu CE, Qin YY and Huang GJ: Gastric Cancer Stem cells: Mechanisms and therapeutic approaches. Yonsei Med J 59: 1150-1158, 2018.

13. Zhan T, Rindtorff $\mathrm{N}$ and Boutros $\mathrm{M}$ : Wnt signaling in cancer. Oncogene 36: 1461-1473, 2017.

14. Carlberg C, Hooft van Huijsduijnen R, Staple JK, DeLamarter JF and Becker-André M: RZRs, a new family of retinoid-related orphan receptors that function as both monomers and homodimers. Mol Endocrinol 8: 757-770, 1994.

15. Feng SJ, Xu S, Wen ZZ and Zhu YL: Retinoic acid-related orphan receptor ROR $\beta$, circadian rhythm abnormalities and tumorigenesis (Review). Int J Mol Med 35: 1493-1500, 2015.

16. Mühlbauer E, Bazwinsky-Wutschke I, Wolgast S, Labucay K and Peschke E: Differential and day-time dependent expression of nuclear receptors ROR $\alpha, \operatorname{ROR} \beta, \operatorname{ROR} \gamma$ and $\mathrm{RXR} \alpha$ in the rodent pancreas and islet. Mol Cell Endocrinol 365: 129-138, 2013.

17. Wen ZZ, Pan TH, Yang SS, Liu JW, Tao HY, Zhao YM, Xu DT, Shao W, Wu J, Liu XY, et al: Up-regulated NRIP2 in colorectal cancer initiating cells modulates the Wnt pathway by targeting ROR $\beta$. Mol Cancer 16: 20, 2017.

18. Risinger JI, Allard J, Chandran U, Day R, Chandramouli GVR, Miller C, Zahn C, Oliver J, Litzi T, Marcus C, et al: Gene expression analysis of early stage endometrial cancers reveals unique transcripts associated with grade and histology but not depth of invasion. Front Oncol 3: 139, 2013.

19. Edge SB and Compton CC: The American Joint Committee on Cancer: The 7th edition of the AJCC cancer staging manual and the future of TNM. Ann Surg Oncol 17: 1471-1474, 2010.

20. Mulcahy DM: The animal welfare act and the conduct and publishing of Wildlife research in the United States. ILAR J 58: 371-378, 2017. 
21. Livak KJ and Schmittgen TD: Analysis of relative gene expression data using real-time quantitative PCR and the 2(-Delta Delta C(T)) method. Methods 25: 402-408, 2001.

22. Huang da W, Sherman BT and Lempicki RA: Systematic and integrative analysis of large gene lists using DAVID bioinformatics resources. Nat Protoc 4: 44-57, 2009.

23. Subramanian A, Tamayo P, Mootha VK, Mukherjee S, Ebert BL Gillette MA, Paulovich A, Pomeroy SL, Golub TR, Lander ES and Mesirov JP: Gene set enrichment analysis: A knowledge-based approach for interpreting genome-wide expression profiles. Proc Natl Acad Sci USA 102: 15545-15550, 2005

24. André E, Gawlas K and Becker-André M: A novel isoform of the orphan nuclear receptor RORbeta is specifically expressed in pineal gland and retina. Gene 216: 277-283, 1998.

25. Tiffon C, Giraud J, Molina-Castro SE, Peru S, Seeneevassen L, Sifré E, Staedel C, Bessède E, Dubus P, Mégraud F, et al: TAZ Controls Helicobacter pylori-induced epithelial-mesenchymal transition and cancer stem cell-like invasive and tumorigenic properties. Cells 9: 1462, 2020.

26. Yang M, Jin M, Li K, Liu H, Yang X, Zhang X, Zhang B, Gong A and Bie Q: TRAF6 promotes gastric cancer cell self-renewal, proliferation, and migration. Stem Cells Int 2020: 3296192, 2020.

27. Azimi M, Totonchi M, Rahimi M, Firouzi J, Sahranavard P, Emami Razavi A, Memari F, Kamali F and Ebrahimi M: An integrated analysis to predict micro-RNAs targeting both stemness and metastasis in human gastric cancer. J Gastroenterol Hepatol 36: 436-445, 2021
28. Slusarski DC, Corces VG and Moon RT: Interaction of Wnt and a Frizzled homologue triggers G-protein-linked phosphatidylinositol signalling. Nature 390: 410-413, 1997.

29. Nguyen LV, Vanner R, Dirks P and Eaves CJ: Cancer Stem cells: An evolving concept. Nat Rev Cancer 12: 133-143, 2012.

30. Schulenburg A, Blatt K, Cerny-Reiterer S, Sadovnik I, Herrmann H, Marian B, Grunt TW, Zielinski CC and Valent P: Cancer stem cells in basic science and in translational oncology: Can we translate into clinical application? J Hematol Oncol 8: $16,2015$.

31. Luo SQ and Rubinsztein DC: BCL2L11/BIM: A novel molecular link between autophagy and apoptosis. Autophagy 9: 104-105, 2013.

32. Mao J, Fan S, Ma W, Fan P, Wang B, Zhang J, Wang H, Tang B, Zhang Q, Yu X, et al: Roles of Wnt/ $\beta$-catenin signaling in the gastric cancer stem cells proliferation and salinomycin treatment. Cell Death Dis 5: e1039, 2014.

33. Tan SH, Swathi Y, Shawna Tan S, Goh J, Seishima R, Murakami K, Oshima M, Tsuji T, Phuah P, Tan LT, et al: AQP5 enriches for stem cells and cancer origins in the distal stomach. Nature 578: 437-443, 2020.

This work is licensed under a Creative Commons Attribution-NonCommercial-NoDerivatives 4.0 International (CC BY-NC-ND 4.0) License. 